\title{
R\&D Intensity and Its Curvilinear Relationship with Firm Profitability: Perspective from the Alternative Energy Sector
}

\author{
Natasha Hazarika
}

Citation: Hazarika, N. R\&D Intensity and Its Curvilinear Relationship with Firm Profitability: Perspective from the Alternative Energy Sector. Sustainability 2021, 13, 5060. https:// doi.org/10.3390/su13095060

Academic Editor: Lluís Miret-Pastor

Received: 20 March 2021

Accepted: 26 April 2021

Published: 30 April 2021

Publisher's Note: MDPI stays neutral with regard to jurisdictional claims in published maps and institutional affiliations.

Copyright: (C) 2021 by the author. Licensee MDPI, Basel, Switzerland. This article is an open access article distributed under the terms and conditions of the Creative Commons Attribution (CC BY) license (https:/ / creativecommons.org/licenses/by/ $4.0 /)$.
Department of Humanities and Social Sciences, Indian Institute of Technology Guwahati, Assam 781039, India; nhazarika2@rnd.iitg.ac.in or nhazarika2-c@my.cityu.edu.hk

\begin{abstract}
There is an inconclusive debate concerning the relationship between environmental research and development (R\&D) and corporate financial performance (CFP). The debate becomes more complex because a win-win situation between environmental and financial goals is not as plausible in practice as it is in theory. Though arguments have been made that when time-lag is considered, the relationship can produce positive outcomes for both entities, ambiguities persist because linear models dominate this analysis. This study, therefore, empirically tested the existence of a curvilinear relationship between R\&D intensity and CFP in the context of the alternative energy sector. Using a panel dataset of 24 companies and 232 unbalanced firm-year observations for 10 years, it was found that after passing the inflection points, investment in R\&D reaps financial benefits that will eventually offset the cost of the initial investment. The curvilinear relationship of R\&D intensity on return on sales and net profit margin is strongly supported.
\end{abstract}

Keywords: corporate financial performance; alternative energy; innovation; R\&D intensity

\section{Introduction}

Since the depletion of the world's conventional energy sources means they will become exhausted in the near future, the development of new technologies and a new knowledge base is considered to be crucial for economic development and for inclusive growth while being cognizant of the limitations of the natural environment [1]. Moreover, evidence of industries being major GHG contributors has provoked immense interest in the interface of industrial processes and environmental consequences, as well as burgeoning importance of shifting to cleaner technologies [2]. As it is expected that the global consumption of energy will increase by $53 \%$ by 2030 [3], increasing the proportion of alternative energy will be one of the key policy agendas of many countries around the world [4]. Alternative energy, if efficiently harnessed, can considerably reduce dependency on polluting energy sources and effectively reverse the ecological imbalances [5] because alternative sources of energy are not solely dependent on fossil fuels and have been found to have a tolerable environmental impact [6]. Some examples of alternative energy are solar energy, wind energy, and fuel cells [6]. Alternative energy is often hailed as "the future of energy," which holds promise for increased energy efficiency, climate change mitigation, and substantial economic benefits [7].

As an increasing number of GHG emitters are held liable for their actions, the need for higher incentives has led to greater research and development (R\&D) into the prospects of alternative energy [8]. A general assumption is that greater investment in R\&D for environmentally sustainable products would improve climate change mitigation [9]. The objective of such R\&D is to provide environmentally safe solutions for production and consumption through improved products, processes, and services. Firms that routinely practice environmental R\&D aim to cultivate the stock of knowledge for enhanced environmental protection for later implementation in constituting new applications [10].

Focusing on the financial profitability from investments in $R \& D$, some studies have suggested that with proper regulatory measures in place, increased innovative practices 
(such as R\&D) would offset the cost of compliance [11] and that greener industries can achieve a higher return than dirtier industries by investing in obtaining ecological differentiation [12]. However, there is a counterargument that R\&D that results in enhanced environmental performance might not necessarily result in enhanced economic performance [13]. For instance, Tsai et al. [14] empirically observed that although R\&D reduces pollution per unit of output and enhances its environmental performance, there are no records that show that R\&D boosts corporate financial performance (CFP). For the alternative energy sector exclusively, arguments exist on both sides of the debate-some suggest that the market potential and employment opportunities brought in by alternative energy technologies would quickly recover the investments made on $R \& D[15,16]$, whereas others state that increased investment on R\&D alone does not guarantee financial profitability for firms $[17,18]$. Moreover, the transition from fossil fuel lock-ins to alternative energy has not yet been as successful because alternative energy, in general, is considered riskier and increasingly speculative [19].

Most of the empirical analyses of firms examining the relationship between R\&D investment and CFP have used linear models, resulting in a negative or a positive relationship. Though it is understood that the reality would be complex, the linear models that are used to improvise on earlier theories are the same theories that are again grounded in linear models $[20,21]$. Theory development may spin in a circle, which is reflected in the fact that, notwithstanding a large number of empirical investigations of the R\&D-CFP relationship, there is no widely accepted theoretical framework [22-24]. Studies have suggested that the use of linear models only interferes with the process of theory development, so a shift from linear to non-linear models has been deemed essential [21,25]. A non-linear or a curvilinear relationship means that the kind of association between explanatory and response variables (be it positive or negative) depends on the extent of the explanatory variable.

In a curvilinear relationship, a U-shaped curve is obtained when an increase in one variable is met by the other decreasing to a certain point, beyond which both the variables increase together. Taking corporate environmental performance (CEP) and CFP as the explanatory and response variables, Trumpp and Guenther [20] demonstrated that these two variables have a curvilinear relationship; in other words, initially, when the level of CEP is too low, it incurs more cost, exhibiting a negative linear relationship, but when higher investments into CEP are made, greater financial returns are realized, exhibiting a growing positive relationship. This is represented by a U-shaped curve. Therefore, a higher CEP would result in a positive CEP-CFP relationship and vice-versa. Similarly, Wang et al. [26] demonstrated a non-linear relationship between corporate social responsibility (CSR) and CFP, where only after crossing the inflection point did a higher investment in CSP result in a higher CFP. Accordingly, this study empirically tested the relationship between R\&D and CFP of the stock-exchange listed companies in the alternative energy sector.

It is intriguing to understand how the R\&D expenditure of alternative energy sector companies, whose core business centers on producing and selling sustainable forms of energy, is related to financial performance. It is assumed that, although R\&D may be initially cost-intensive, it is capable of creating substantial financial benefits once it attains a degree of maturity, i.e., R\&D-CFP has a U-shaped curvilinear relationship. This study was peculiar because in studies of the alternative energy industry, although the means to improve financial health have been captured from various standpoints (such as the importance of state-sponsored investments [27], impacts of technology stock prices, oil prices [28], impacts of local market returns [29], and the effect of additional state-induced investment for promoting R\&D [30]), there have been a negligible number of empirical studies exclusively examining the impact of private R\&D expenditure on firms' financial performance in the alternative energy sector.

In the following section, theories and hypothesis of the research are demonstrated, with a subsequent section on methodology elaborating on the constructs of R\&D and CFP, along with an explanation on the indicators in the data and variables section. Results, discussion, and concluding remarks with the way forward comprise the rest of the paper. 


\section{Literature Review}

\subsection{RED in the Alternative Energy Sector}

One of the core industries that heavily rely on R\&D is the alternative energy industry. The outreach of this industry has been steadily growing across the world over the years, with Europe being the leading investor [31]. Both government-funded programs and private companies have been crucial in generating new knowledge to continuously help the energy sector in evolving from non-renewable to renewable sources of energy [17]. Considering that the non-renewables will soon be exhausted, it is important to establish that for every extracted barrel of non-renewable resources, one barrel of alternative energy is readily available so that the stock of natural capital cannot fall if the current growth rate is maintained or accelerated [32].

Overall, however, the total investment made into renewable or alternative energy is significantly less than the investments in the electricity, oil, and gas sectors, making three-fifth of the total investments made on energy in the year 2016 [3]. Of the $\$ 67$ billion spent worldwide on energy R\&D in 2015, most private sector investments went gone to oil, gas, and thermal power generation; on the other hand, R\&D spending on alternative energy technology has not significantly risen since the past four years [3]. The reasons for restricted $R \& D$ spending on alternative energy are two-fold: first is the inherent riskiness associated with R\&D activities, which is valid for not only the alternative energy sector but also other sectors like tech industries and healthcare [33], and second is the set of systematic problems that are specific to the alternative energy sector [34]. Each of these issues is discussed below.

Inherent Riskiness

Inherent riskiness with the R\&D activities is explained as the typical neoclassical economics issue of market failure constituted by technological uncertainty and long-term investments [17,35], coupled with the emergence of "new normal" for growth, which has led to investors tightening their stance on R\&D expenses. Before the global financial crisis in 2008 , investors used to have a leap-of-faith mindset with $R \& D$, and scientists were allowed time and space to pursue their interests lest the pressure for a return interfered with the quality of innovation [36]; however, after 2008, a fall in market demand and increased macroeconomic uncertainties invariantly reduced firms' incentives and opportunities for investing in innovation-oriented $R \& D$ [37]. Though now recovered, $R \& D$ has since increasingly measured in relation to CFP, which helps in delineating the prospects of a return on each $R \& D$ project in order to determine if funding is to be continued or reduced [36].

Market Receptivity

Systematic problems are characterized by various aspects of the innovation process that are specific to the alternative energy industry. One of the core aspects is the market structure in which the alternative energy sector needs to compete with the incumbent firms practicing conventional forms of energy [38]. Incumbent firms often demonstrate willingness for incremental innovation for alternative technologies that complement the traditional energy system which is also supported by policies; this strategy prevents higher investment in R\&D in core alternative energy firms that are devoted to radical innovations [39]. For example, in countries like the Netherlands and the UK, policies support biomass co-combustion, which means an addition of biomass to coal-firing plants that not only gives higher leverage to coal lock-ins but also deviates investments from radical alternative innovations [40]. Moreover, compared to incumbent technologies, alternative energy technologies suffer from a lack of scale and experience economies, as well as poor initial performance compared to conventional energy sectors that have established themselves in the socio-economic paradigm through years of technological learning [41]. Such issues of market structure can only be resolved through government interventions, especially in the form of policies that can help bridge the gap [42].

Institutional Atmosphere 
However, contrary to popular belief, institutional issues related to policies have instead acted as barriers to alternative energy development. For instance, the introduction of highly volatile policies, such as the stop and go policies in the Netherlands during which subsidies for alternative energy R\&D were stopped every two years from 1998 to 2011 and were re-introduced in an altered form before being stopped again completely [34], as well as the changing attention of policymakers with regard to global issues that has resulted in the untimely dwindling of funding and provisions as opposed to initial declarations, have made entrepreneurs and investors reluctant to invest in alternative energy R\&D [43].

Consumer Acceptance

Numerous studies from innovation management literature have highlighted that not only producers but also consumers or users participate and shape the innovation process $[44,45]$. Rennings' [46] theory of technology push, market pull, and regulatory push-pull effect for environmental innovation attributes consumer demand as a key component for the diffusion of such innovations. Collaboration with stakeholders or demands from citizens in general who are environmentally sound and proactive lead to increased investment in environmental R\&D because firms are encouraged to maintain their goodwill and consumer base [47]. However, the absence of demand due to the inexperience of consumers or other stakeholders in having to make such decisions regarding whether they are willing to pay for alternative sources of energy against the routine provided by the conventional sources of energy further challenges the investment in $R \& D$ in the alternative energy sector [48].

Infrastructure Availability

Another aspect that is crucial to the alternative energy sector is the availability of appropriate physical infrastructures upon which the core function can run. Unlike conventional energy mechanisms, alternative energy mechanisms require different and specific infrastructures that, again, cost-intensive and might hinder subsequent investment in R\&D [49]. For example, the use of renewable automotive fuel is mainly dependent on the availability of another infrastructure, and in the absence of this refueling infrastructure, investment in renewable automotive fuels is null and void [50].

Therefore, from the system innovation perspective, $R \& D$ investment in the alternative energy sector greatly differs from R\&D investment in regular tech industries. However, R\&D spending on this sector cannot be compromised when considering that alternative sources of energy are identified as the only means that can address the emerging global energy crisis. It has been argued that in addition to a stable and long-term policy framework, sustained investment is required for these technologies to diffuse and achieve their true potential [35]. Therefore, this paper further builds on the R\&D-CFP relationship in the alternative energy sector and demonstrates how sustained investment would result in greater financial returns.

\subsection{The RED-CFP Relationship}

There is a large set of literature dealing with the credibility of R\&D as an intangible asset of firms, which has confirmed that R\&D plays a crucial role in enhancing firm value. The accumulation of intellectual property rights through expenditure on $R \& D$, for example, has been found to create a competitive advantage for businesses, both by means of financial outcomes and as a key market player [51]. Though R\&D is considered an important component for the overall growth of corporations, some studies have demonstrated that R\&D, in particular, does not make a significant contribution to firms' financial performance $[13,52,53]$.

However, R\&D takes a long time to formulate innovation, which might or might not be serendipitous, so it is wise to understand R\&D in relation to future earnings. The time lag is therefore a major issue that needs to be considered when comparing R\&D with CFP [54]. In investigating the relationship between $R \& D$ and future earning variability, studies have made use of patent counts and patent citations as proxies for the economic value of $R \& D$, which has exhibited a positive relationship between a firm's future earnings and R\&D 
expenditure, concluding that this relationship is stronger for firms that continue their $R \& D$ investments [55]. Dave et al. [56] analyzed Standard and Poor's 500 listed companies in the chemical and allied products industry, and they found a strong positive relationship between sales revenues and R\&D investment; they stated that financial sustainability is strongly backed up by gross margins, which are dependent on RDI. However, the time lag that exists from when $R \& D$ expenditures are made and financial sustainability is realized varies from industry to industry [24].

Most technological innovations exhibit an S-shaped performance curve throughout their lifetime when plotted against financial investment and overall efforts [57]; in other words, at the initial stages of the technology, gains in terms of performance would be relatively slow given that the new technology is poorly understood [57]. As a deeper understanding of the technology and its many facets is obtained, returns begin to increase. Firms concentrate their attention on those attributes that bring the most returns per unit of effort, resulting in increased performance. To obtain an S-curve, the invested effort must be constant over time [57]. Moreover, if a disruptive technology has a steeper Scurve exhibiting return on investment to be higher than that of the incumbent technology, newer firms entering the market would opt for the new technology [58]. Accordingly, in a study comparing the performance of R\&D investment in fossil fuel technologies against alternative energy technologies across countries, it was observed that the S-curve for alternative energies is significantly steeper (with an increase in return as a function of R\&D investment) compared to that for fossil fuels [16]. This finding indicated that countries around the world are probably spending excessively on the R\&D of fossil fuels, as it is not translating into palpable performance improvements; however, on the other hand, cost records show that fossil fuels are significantly cheaper than alternative sources of energy, so they are continued to be utilized in bulk for commercial consumption [16]. R\&D in the alternative energy sector is significantly under-funded in relation to its potential payoff; therefore, it is assumed that with a modest investment, these energies can become economically equivalent to fossil fuels. This rate of performance improvement in alternative energy in relation to R\&D investment calls for an increased effort to obtain higher gains.

Due to the concepts of time lag and technology curve, it is expected that the costs incurred by R\&D would initially be higher than the realized profits; however, after passing the inflection points, with continuous investments in R\&D, it will bring financial benefits. Therefore, this study hypothesizes that the RDI and CFP of the alternative energy sector have a U-shaped curvilinear relationship.

\section{Methodology}

\subsection{Constructs}

\subsubsection{R\&D}

Total expenditure on R\&D and RDI are the two key measures to determine the amount of resources allotted for the development of innovative technologies and services. While expenditure on R\&D is the straightforward observation of the total amount of money spent, RDI is used to depict the proportion of total R\&D expenses to the total net sales of a company [59]. It has been debated whether expenses on R\&D should rather be capitalized and measured as an asset instead of an expense, which it is currently considered to be. However, this assumption would have a direct impact on basic calculations relating to a company's value and profitability because capitalizing R\&D would indicate higher assets on the balance sheet, which might raise the value of the company. On the other hand, if costs are not treated as expenses, the profits of the company would appear to be higher (at least on paper). This, in turn, might interfere with securing the investor capital that the company needs for growth-particularly for small- and medium-sized companies. Additionally, as there is no way to reliably measure future financial gains from $R \& D$ expenditure, capitalizing R\&D would not be completely effective. Beld [59] further stated that, by capitalizing $R \& D$, the effects are equalized from the time of its development to its 
final use. Moreover, capitalizing on R\&D is not feasible due to the lack of an amortization rate [59]. Therefore, $R \& D$ investments were used as a measure of expense in this study.

\subsubsection{Corporate Financial Performance}

The measurement of CFP falls largely under the classification provided by Orlitzky et al. [60], i.e., market-based (investor returns), accounting-based (accounting returns), and perception based (survey). Market-based measures include price-per share or share price appreciation, which depicts shareholders as the primary stakeholder group. Stock performance, market value to book value, and market returns are some of the marketbased measures [61]. Accounting-based measures include a firm's return on assets (ROA), return on equity (ROE), return on sales (ROS), net profit margin (NPM), and earnings per share (EPS), which also shows a firm's internal capacity [60]. While accounting-based measures are objective and audited, market-based measures are partially objective, whereas perceptual-based measures are subjective because they are derived from survey analyses that depend on people's perceptions of the financial performance of firms. Perceptualbased measures include such estimates as the "judicious use of corporate assets," "level of financial goal achieved," and "dependability of financial position" [60].

For this study, indicators primarily belonging to accounting-based measures were considered because a general rule-of-thumb recommends using objective measures in empirical studies for the better estimation of a company's profitability [62]. It is also needed to be considered that some measures such as stock prices represent short-term financial performance, whereas other measures such as ROE represent long-term financial performance [63]. Another general principle when comparing companies for their economic performance through accounting-based measures is to adhere to a single industry because the units of accounting-based measures are dependent on equity, liability, assets, etc., that widely vary from industry to industry. A service-based industry such as the banking sector, for instance, would have far less hard resources than manufacturing industries, so the total assets of the latter cannot be compared with those of the former. For the sake of accuracy and consistency, the accounting-based measures that represent long-term financial performance for companies operating under the alternative energy sector were considered in this study.

\subsection{Data and Variables}

\subsubsection{Data Sampling}

The sample-set for testing the relationship between RDI and CFP was derived from the set of companies listed in renewable-energy-industry and alternative energy stocks websites.

1. The renewable-energy-industry website profiles international companies from the green industry with regard to their products, services, and other offerings. The Renewable Energy Industrial Index (RENIXX) highlights the largest companies listed on the stock exchange.

2. The alternative energy stocks website profiles a range of alternative and renewable energy companies that either produce energy from renewable sources or from environmentally safe sources for investors to make informed investments in the alternative energy sector.

The only companies considered for the study were those that fulfilled the following criteria:

(i) The companies and their financial data, i.e., balance sheets and income statements, are all listed because they could be retrieved from popular stock exchange sites; for this purpose, Morningstar.com was used to retrieve data on 11 February 2018.

(ii) Firms belonging to an industry might or might not have any R\&D activities [64]; therefore, for the sake of accuracy, the only firms that were selected were found to have a stable investment in R\&D from 2007 to 2016, i.e., 10 years of R\&D investment.

(iii) The company provided data for all the indicators (RDI, ROA, ROE, EPS, ROS, NPM, DE Ratio, and SIZE). 
This resulted in a panel of 24 companies (appended as Table A1) from 2007 to 2016, representing 232 observations ( 24 firms $\times 10$ Years -8 missing observations).

\subsubsection{Independent Variable}

The independent variable is RDI, which is used for measuring the amount of investment in R\&D. RDI is calculated as the proportion of total R\&D expenditure to the total net sales of a company. RDI is widely used by policymakers and researchers across countries and industries to estimate the level of innovation or strength of technological capacity [64]. Industries are classified into groups of high, medium, and low technology based on their RDI [64], the validity of which depends on the RDI variable being able to accurately reflect the innovative behavior of firms. RDI therefore reflects a company's interest in advancing its innovative capacity through basic and applied research because its end goal is to increase its factor productivity as a saleable output [65].

\subsubsection{Dependent Variables}

The dependent variables are the measures representing CFP. For this purpose, objective indicators were chosen from accounting-based methods, i.e., ROA, ROE, EPS, ROS, and NPM. ROA is measured as the proportion of net income to total assets. ROA shows how effective a firm is in converting the money it invests into income, so the higher the ROA of a company, the better the company is at obtaining more profit from less investment [66]. ROE is measured as the proportion of net income to total stockholders' equity. ROE measures the profitability of a company by showing how much the company earns with the money shareholders invest in it. Moreover, ROE is used not only for determining profits but also for efficiency. Chen and Hwang [67] found a positive link between RDI, ROA, and $\mathrm{ROE}$, and they emphasized the importance of R\&D efforts for future profitability and revenue growth.

EPS is the part of the profit of the company allotted to each of the outstanding shares of the common stock [68]. EPS is calculated as net income less dividends on preferred stock to average outstanding shares. EPS can be considered as the most important variable for the determination of share prices. ROS effectively calculates a company's capability of generating profits from its revenue [69]. Investors, debt holders, etc. examine this ratio before making an investment decision because it substantively highlights the proportion of the operating cash a company can earn on its revenue. Lastly, NPM is considered to be an important factor for understanding a firm's financial health [70]. NPM is calculated as the ratio of net income to revenue. By keeping track of the rise and fall of the NPM, a business can determine if the ongoing functions are beneficial or not. Additionally, NPM can be used for forecasting profits based on revenue. The involved data were retrieved from annual firm-specific balance sheets and income statements.

\subsubsection{Control Variables}

The sample of alternative energy companies was from the same industry. The two chosen control variables were firm size and the debt/equity (D/E) fraction. Firm size was measured as the natural log of the company's total assets. As the variance of the total assets of companies usually varies according to their value, the natural log was taken in order to normalize their distribution and to help satisfy the parametric assumptions embodied in regression analysis [26]. In addition, the D/E fraction was taken as a control variable because it control whether a firm's performance is impacted by liability or leverage [26]. It is measured by dividing the total amount of liability by the total amount of shareholders' equity. This fraction also provides an insight into the financing and risk preferences of a company. 


\subsection{Statistical Methods}

\subsubsection{Stationarity Test}

Before conducting the panel data analysis, the variables were subjected to a unit root test in order to determine their stationarity. Considering that the panel data were unbalanced, the Fisher-type-unit root test conducted through the Dickey-Fuller test was chosen. As shown in Table 1, the Dickey-Fuller test showed that it was stationary at the first difference, which means the data were considered stable when lagged by one period. Since the null hypothesis pertained to non-stationarity, that the $p$-values for all the variables were less than 0.01 , thus showing stationarity; therefore, the panel data were considered ready for further analysis.

Table 1. Stationarity test using Fisher type Dickey-Fuller test.

\begin{tabular}{|c|c|c|c|c|}
\hline & $\begin{array}{c}\text { Inverse } \\
\text { Chi-Square }\end{array}$ & Inverse Normal & $p$-Value & Output \\
\hline RDI & 203.1479 & $\begin{array}{c}\text { Independent Variable } \\
\quad-10.5451 \\
\text { Dependent Variables }\end{array}$ & 0.000 & Stationary \\
\hline ROA & 124.4593 & -6.0197 & 0.000 & Stationary \\
\hline ROE & 86.6617 & -3.1510 & 0.000 & Stationary \\
\hline EPS & 184.2309 & -9.2696 & 0.000 & Stationary \\
\hline ROS & 209.9396 & -10.7610 & 0.000 & Stationary \\
\hline NPM & 227.2884 & $\begin{array}{l}-11.4339 \\
\text { Control Variables }\end{array}$ & 0.000 & Stationary \\
\hline $\begin{array}{l}\text { DE- } \\
\text { Ratio }\end{array}$ & 212.9107 & -10.2690 & 0.000 & Stationary \\
\hline SIZE & 102.9124 & -5.2712 & 0.000 & Stationary \\
\hline
\end{tabular}

\subsubsection{The RDI-CFP Relationship}

Two models were adopted to test the hypothesis. The first was a simple model to determine the linear impact of $R D I$ on $C F P$, depicted as:

$$
\begin{gathered}
C F P_{i t}=\beta_{0}+\beta_{1} R D I_{i, t}+\beta_{3} D E_{i, t}+\beta_{4} \text { LogFirmSize }_{i}+\beta_{5} \sum \text { TimeEffect }_{i, j}+\varepsilon_{i, t} \\
C F P_{i t}=\beta_{0}+\beta_{1} R D I_{i, t}+\beta_{2} R D I 2_{i, t}+\beta_{3} D E_{i, t}+\beta_{4} \text { LogFirmSize }_{i}+\beta_{5} \sum \text { TimeEffect }_{i, j}+\varepsilon_{i, t}
\end{gathered}
$$

where subscripts $i$ represent individual firms, $t$ represents time, and $j$ represents time effect dummy variables. $C F P_{i t}$ is the dependent variable of corporate financial performance, $R D I_{i t}$ is the independent variable of research and development intensity, and $R D I 2_{i t}$ is its quadratic term. $D E_{i t}$ and LogFirmSizei are control variables representing the debt/equity fraction and size of a firm. TimeEffectij represents dummy variables for the time effect; $\beta_{0}$ is the intercept; $\beta_{1}, \beta_{2}, \beta_{3}, \beta_{4}$, and $\beta_{5}$ are the coefficients of the corresponding items; and $\varepsilon_{i t}$ is the error term. This method is widely acknowledged and has been implemented by scholarly work, e.g., Wang et al. [24], Trumpp and Guenther [20], Abiad and Mody [71], and Kalemli-Ozcan et al. [72].

The panel data analysis was carried out by employing three models, i.e., the pooled regression or the least-squares model, the fixed-effects model, and the random-effects model. For model selection, a Lagrange multiplier test was carried out where appropriate for comparing the random effects model with the pooled regression model, the F-test was used to compare the fixed effects model with the pooled regression model, and the Hausman test or Hansen's J test was carried out to determine whether the studied model is random or fixed effect $[24,73]$

\section{Results}

The descriptive statistics for all the variables are summarized in Table 2. The percentage of RDI was $452 \%$ per annum. The average ROA for each of the firms was $-18 \%$ per annum, ROE was $-55 \%$ per annum, ROS was $-625 \%$ per annum, and NPM was 
$-621 \%$ annum. For EPS, its average value was -68 dollars per year, with a maximum of 91.5 dollars per year. For the control variables, the D/E fraction had a mean of 1.762, and the log of firm size had a mean of 20.558 .

Table 2. Descriptive Statistics of the independent variable, dependent variables, and control variables.

\begin{tabular}{cccccc}
\hline & Variable & Mean & Std. Dev. & Confidence Value & Confidence Interval \\
\hline IV & RDI & 4.523 & 56.475 & 23.84771 & -19.33 and 28.37 \\
DV & ROA & -0.1754 & 0.4285 & 0.180978 & -0.356 and 0.005 \\
& ROE & -0.5549 & 3.7005 & 1.562612 & -2.117 and 1.007 \\
& ROS & -6.246 & 72.021 & 30.41183 & -36.65 and 24.16 \\
& NPM & -6.213 & 70.458 & 29.75193 & -35.96 and 23.53 \\
& EPS & -68.82 & 744.70 & 314.4623 & -383.3 and 245.6 \\
CV & DE Ratio & 1.762 & 12.312 & 5.199041 & -3.436 and 6.962 \\
& SIZE & 20.55 & 2.1559 & 0.910366 & 19.65 and 21.47 \\
\hline
\end{tabular}

As for the confidence intervals for each of the variables, it can be observed from Table 2 that in each of the cases, the intervals provided a range of plausible values for the variable mean. Hence, it can be said that the observed means for all the variables could be their true values.

The effect of RDI on the five CFP indicators is shown in Table 3. The dependent variables of CFP are shown in the first row, and the independent variables of RDI and RDI2 are shown in the first column, along with the control variables of the $\mathrm{D} / \mathrm{E}$ fraction, the log of firm size, and the set of dummy variables from X2008 to X2016 denoting the time effect. It was found that RDI had no statistically significant relationship with EPS, probably because EPS is influenced by different factors and cannot be exclusively attributed to RDI. Similarly, ROE also did not appear to have any significant relationship with RDI. In terms of the other indicators of ROA, ROS, and NPM, significant relationships appearred. The derivatives from model 1 showed a significant negative linear relationship of RDI on ROA, ROS, and NPM, with coefficients of $-0.201,-0.998$, and -0.997 , respectively, and $p$-values being less than 0.001 in all three cases. When the quadratic term of RDI was added in model 2, it appeared to have a significant effect on ROS and NPM. The coefficient of RDI2 was 0.336 for model 2 of ROS, and the coefficient of RDI2 was 0.457 for model 2 of NPM, with $p$-values being less than 0.001 in both cases.

Table 3. Estimation results for curvilinear model.

\begin{tabular}{|c|c|c|c|c|c|c|c|c|c|c|}
\hline & \multicolumn{2}{|c|}{ ROA } & \multicolumn{2}{|c|}{ ROE } & \multicolumn{2}{|c|}{ ROS } & \multicolumn{2}{|c|}{ NPM } & \multicolumn{2}{|c|}{ EPS } \\
\hline & Model 1 & Model 2 & Model 1 & Model 2 & Model 1 & Model 2 & Model 1 & Model 2 & Model 1 & Model 2 \\
\hline RDI & $-0.201 * * *$ & 0.6 & 0.0118 & -1.292 & $-0.998^{* * *}$ & $-1.335^{* * *}$ & $-0.997 * * *$ & $-1.456^{* * *}$ & 0.0101 & -0.533 \\
\hline RDI2 & $\mathrm{n} / \mathrm{a}$ & -0.801 & $\mathrm{n} / \mathrm{a}$ & 1.304 & $\mathrm{n} / \mathrm{a}$ & $0.336^{* * *}$ & $\mathrm{n} / \mathrm{a}$ & $0.457^{* * *}$ & $\mathrm{n} / \mathrm{a}$ & 0.541 \\
\hline DE Ratio & 0.00219 & 0.00218 & $-0.707^{* * *}$ & $-0.710^{* * *}$ & 0.000225 & 0.000914 & 0.000285 & 0.000993 & -0.00179 & 0.00498 \\
\hline SIZE & $1.104^{* *}$ & $1.116^{* *}$ & $0.139 * *$ & $0.114 *$ & 0.0154 & $\underset{* * *}{0.00511}$ & 0.0225 & $0.00460 *$ & 0.113 & 0.0984 \\
\hline X2008 & -0.211 & -0.231 & -0.00931 & 0.0294 & -0.0113 & -0.00339 & -0.0159 & -0.00607 & 0.000735 & -0.000141 \\
\hline X2009 & -0.184 & -0.192 & -0.0338 & -0.00807 & -0.00329 & 0.00109 & -0.00425 & 0.000657 & -0.00344 & -0.0296 \\
\hline X2010 & $-0.280 *$ & $-0.280 *$ & -0.069 & -0.0562 & 0.00109 & 0.00263 & -0.000875 & 0.000654 & -0.606 & $-0.636^{*}$ \\
\hline X2011 & $-0.584 *$ & $-0.583^{* *}$ & -0.106 & -0.097 & -0.0114 & -0.0105 & -0.0135 & -0.0127 & -0.0689 & -0.101 \\
\hline X2012 & $-0.681^{* * *}$ & $-0.687^{* * *}$ & -0.142 & -0.121 & -0.00669 & -0.00303 & -0.00784 & -0.0032 & -0.0455 & -0.0739 \\
\hline X2013 & $-0.597^{* *}$ & $-0.602^{* *}$ & 0.058 & 0.08 & -0.00546 & -0.00172 & -0.00865 & -0.00391 & -0.0254 & -0.0542 \\
\hline X2014 & $-0.506^{*}$ & -0.504 * & -0.32 & -0.312 & -0.00207 & -0.000926 & -0.00565 & -0.00427 & -0.0111 & -0.0409 \\
\hline X2015 & $-0.875^{* *}$ & $-0.876^{* *}$ & -0.275 & -0.26 & -0.00808 & -0.00575 & -0.0130 * & -0.00987 & -0.0142 & -0.0447 \\
\hline X2016 & $-0.890 *$ & $-0.890 *$ & -0.335 & -0.319 & -0.0112 & -0.00901 & -0.0179 & -0.0148 & -0.0034 & -0.0392 \\
\hline Effect & Fixed & Fixed & Pooled & Pooled & Fixed & Pooled & Fixed & Pooled & Pooled & Pooled \\
\hline $\begin{array}{l}\text { Adj. R } \\
\text { square }\end{array}$ & 0.397 & 0.397 & 0.52 & 0.523 & 0.999 & 1 & 0.999 & 0.999 & -0.008 & -0.012 \\
\hline
\end{tabular}

Note: ${ }^{*} * *$, and ${ }^{* * *}$ indicate significance at the $0.05,0.01$, and 0.001 levels, respectively. The set of dummy variables from X2008 to X2016 denote the time effects. 
Both ROS and NPM appeared to make the strongest cases for having a curvilinear relationship between RDI and CFP, with the values of adjusted R-square being very strong both times. ROA showed a negative linear relationship with RDI in model 1, which was expected, although it did not have a significant relationship with the RDI quadratic term. This could have been because the data were only for ten years, which might not have been sufficient to depict the exact return on company profitability through all its indicators compared to its R\&D expenditure [74].

The two models for the impact of RDI on ROS are:

$$
\begin{aligned}
& \text { ROS }=-0.998 \times R D I+0.00023 \times E+0.0154 \times \text { LogFirmSize }+ \text { Items }(\text { TimeFixedEffects }), R D I[0,1] \\
& R O S=-0.336 \times(R D I-1.99)^{2}+0.00092 \times D E+0.0052 \times \log \text { FirmSize }+ \text { Items }(\text { TimeFixedEffects }), \text { RDI }[0,1]
\end{aligned}
$$

Similarly, the two models for the impact of RDI on NPM are:

$$
\begin{gathered}
N P M=-0.997 \times R D I+0.00029 \times D E+0.0225 \times \operatorname{LogFirmSize}+\text { Items }(\text { TimeFixedEffects }), R D I[0,1] \\
N P M=0.457 \times(R D I-1.60)^{2}+0.000993 \times D E+0.0046 \times \text { LogFirmSize }+ \text { Items }(\text { TimeFixedEffects }), R D I[0,1]
\end{gathered}
$$

\section{Discussion}

Because $R \& D$ requires a large amount of time and money to be invested at an early stage and the new technology that is developed has to struggle to thrive among incumbent technologies, the financial performance of firms would decline as expenditure on R\&D increases when R\&D is relatively low [74]. However, when R\&D reaches a level of maturity, new technologies would produce tangible and intangible outcomes, such as the product and its brand value [75] with increased trust and customer satisfaction [75], resulting in higher diffusion that would then be reflected in a firm's financial performance. With increased recognition in the market, its sales would shoot up. This would generate profits while not imparting additional costs for acquiring resources, thus enhancing return on sales and net profit margin, as represented by ROS and NPM. After passing the inflection points, RDI was found to be positively related to CFP.

As the hypothesis conjectured, it was found that RDI had a U-shaped relationship with CFP (measured by its indicators ROS and NPM). The inflection points for ROS and NPM did not vary too much, with the one for ROS being approximately 2 and the inflection point for NPM being over 1.6. However, it could still be stated that benefits from R\&D expenditure would be easier to be obtained for NPM than for ROS because the inflection point of NPM was found to be smaller than that of ROS. The inflection points would be utilized by firms to focus on those aspects that would help reach the inflection points sooner, and higher efforts would be invested on those aspects.

The two indicators of ROS and NPM used in this study were considered very strong for realizing financial performance across firms because they do not consider the type of financing a firm uses, i.e., the differences in debt and equity are not factored into the equation so they depict a better picture when firms of varied sizes are brought together. As for ROE, equity is the difference between asset and liability or, in other words, financial leverage for which the $\mathrm{D} / \mathrm{E}$ fraction can be considered a proxy. That the coefficients of the $\mathrm{D} / \mathrm{E}$ fraction happened to be significant for models 1 and 2 of ROE while being insignificant for ROS and NPM indicates that liability or financial leverage could be the responsible factor for the absence of a curvilinear relationship between RDI and ROE.

Finally, the study found that a curvilinear relationship existed between RDI and ROS and between RDI and NPM; there was also evidence of a significant linear relationship between RDI and ROA that did not conform to a curvilinear relationship. On the other hand, it was found that ROE and EPS had no statistically significant relationship of any description with RDI.

The results from this empirical study provide evidence that investing in $R \& D$ in the alternative energy sector would accelerate financial gains and that the notion of the inevitable struggle between economy and environment arises from a stalemate view of the environmental regulations, whereas superior productivity, innovative outputs, and 
greater efficiency can indeed bring a win-win situation between the two, in line with the assumptions made by Porter and Linde [76]. Most companies working in the alternative energy sector need to invest in R\&D and are primarily founded on this basis-in the absence of which the alternative energy industry may even cease to exist. However, because R\&D is relatively cost-intensive, many companies in the alternative energy sector do not appear to be proactive in spending on it. Moreover, the income statements of some of these companies have shown a decline or a complete halt in R\&D investment after a few years, following which these companies function more like service providers. This might explain the difficulty encountered in sampling companies that have a consistent investment in R\&D.

However, as it was observed that the financial performance of firms improved with higher investment in $\mathrm{R} \& \mathrm{D}$, this may partially explain why large, well-known companies tend to annually increase their investment in R\&D. Research has found that the scale of firms also has an impact on their private $R \& D$ expenditure, i.e., larger and reputed firms tend to take risks and are willing to spend more on R\&D [30]. The decision to go green itself provides a peculiar stature to its practitioners that sets them apart from their non-green competitors [77], and for companies like Tesla and Ballard power, it has worked in their favor in attracting more customers, especially in developed countries. Higher environmental performance strengthens a firm's image, reputation [78], as well as its business relationships [79], because of which it attracts consumers who are willing to pay a relatively higher amount if it guarantees long-term viability and cleaner operation [80].

Nevertheless, because R\&D in the alternative energy sector is associated with the double externality problem that causes both knowledge and environmental externalities during the innovation and diffusion phases, it leads to private returns being lesser than the social returns. As per Popp [81], in the case of alternative energy, the private return on $R \& D$ expenditure is four times less than that of the social return.

The findings, therefore, indicate the importance of the combined effect of policy style, policy instruments, and stakeholders for invention and innovation, as well as the importance of strategic niche management and network sustainability at diffusion to break out of the risks and systematic issues surrounding alternative energy. This is because although $R \& D$ is a powerful tool, it requires the continuous collaboration of the surrounding factors to remain viable in the market [82].

Policy style is a pre-condition that determines the future receptivity and sustenance of the policy schemes introduced to support the prospects of alternative energy. It refers not only to the style of implementation of specific instruments and policy contents and the nature of the network of communities involved in the implementation of policies but also to the forms of challenges that can result in legislative changes [83]. For alternative energy firms to proactively sustain their investment in $\mathrm{R} \& \mathrm{D}$, the environmental policies have to be calculable, reliable, and have the ability to continue even in the face of institutional change [84]. Decisiveness and commitment exhibited by the government in the implementation of ambitious environmental goals would motivate private firms and reduce their uncertainties regarding investments and profit, which would help break out of the inherent riskiness and the problems of the institutional atmosphere. Further, it is suggested that policy instruments work best when they are implemented in combination. The coupling of instruments is purely context-specific, but several studies have affirmed that a combination of stringency and rewards work best for sustained environmental innovations [85]; for instance, innovation policy by means of financial support, primarily by the public sector, for prototyping, organizing, and marketing demonstration projects can help cut the initial costs of technological innovation, whereas environmental policies can be implemented for internalizing the external costs imposed by existing conventional forms of energy, such as the cheap availability of coal. Such an approach would help in creating a strategic niche market.

As represented by the findings, since $R \& D$ in alternative energy requires continuous efforts in the face of financial instability in the initial years, it needs a certain determination 
in its primary stakeholders. This concept of (an individual or organizational) behavioral trait can be analyzed from various aspects. For instance, it could be the personal values of the managers that impact their discretionary investment on environmental R\&D even at the cost of an initial loss [86] or the values and beliefs of a few decision-makers that play such a strong role that, despite the associated financial risks involved, such organizations adhere to championing ecological responses [87]. On the other hand, organizational identity can also play a vital role, as it can be summarized by drawing from organizational identity theory that actions are legitimized as the company's economic interests when a shared interpretive scheme becomes an integral part of organizational identity [88], i.e., greater investment in R\&D.

Just and effective combination of policy style, policy instruments, and stakeholders can result in the effective implementation of pilot plants or demonstration plants, which can substantially address demand issues, i.e., the more the society is exposed to new sources of energy and get accustomed to its use, the more it is likely to continue its use. Since the likelihood of adoption is greatly influenced by the observability of results and perceived profitability [89], the more the users become familiar with its associated benefits, the more they are likely to demand it. In other words, network sustainability would be achieved with higher diffusion that would eventually supersede the initial costs of R\&D expenditure.

Theoretically, several insights drawn from the findings create opportunities for future research into evaluating policy style and policy instruments in the context of regions that can effectively demonstrate how differences in these factors impact investments on R\&D in alternative energy. On the other hand, the empirical findings should be useful for practitioners in the field of alternative energy, in that increased investment in R\&D is likely to improve accounting-based measures by providing an opportunity to capitalize; it also adheres to the long-standing debate that at least seven years of continuous effort is required to have a positive impact on current financial performance [90]. Once the inflection point of these measures is crossed, $R \& D$ results in an increased profitability, so it is suggested that R\&D expenditures could be equated with the accounting-based measures of ROS, NPM, and ROA through scenarios to maximize profitability and innovation.

\section{Conclusions and Way Forward}

This paper empirically tested the existence of a curvilinear relationship between the much-debated entities of RDI and CFP in the context of the international alternative energy industry. Using a panel dataset of 24 alternative energy companies and 232 firm-year observations over the sample period of 2007-2016, the curvilinear relationship of RDI on ROS and NPM, as measures of CFP, was strongly confirmed, while a negative and linear effect of RDI on ROA was also confirmed. However, there was no statistically significant relationship between RDI, ROE, and EPS. Therefore, it can be stated that RDI might initially have no significant linear relationship with the indicators of financial performance, but financial benefits would be realized with an increase in R\&D investment - thus having a conclusive positive curvilinear relationship.

The established relationship between RDI, NPM, ROS, and ROA has significant implications. Companies investing in alternative energy R\&D are at a high risk of being distracted by the opportunity costs involved because market failure due to knowledge spillovers and free-riders often interfere with a company's ability to capture the whole value of their R\&D investment. However, this analysis indicated that it is only at a low level of R\&D investment that the opportunity costs would be higher, whereas the window of opportunity costs become smaller as a higher income is realized with increased R\&D investment. The situation would improve over time, and, after crossing the inflection point, a higher investment in R\&D appears to be worthwhile. This also partially explains the tendency of companies already investing a large amount in R\&D to further increase their investments annually. This finding emphasizes the importance of organizational management and the long-term commitment of the primary stakeholders for the realization of "it pays to be green". 
This curvilinear relationship between RDI and CFP is important from the policy perspective because it justifies the various policy schemes that have been designed to facilitate private enterprises to break out of the fossil fuel lock-in. Economic instruments for reducing costs and accelerating the market penetration of alternative energy, feed-in tariffs, feed-in premiums, financial support for domestic R\&D [91], and subsidies for green innovation [92] can indeed be better designed in combination with regulatory instruments. This it would offer the sustained investment security required for leveraging the significant amount of capital needed for supporting private investment in R\&D. The need for policies for the promotion of niche technology for market diffusion, as suggested by Bointner [93], was supported by the findings of this study.

The establishment of the curvilinear relationship indicates that future studies of the RDI-CFP relationship should move beyond the linear relationships associated with rigid, either-or thinking that overlooks the possibility of changing dynamics. Future work concentrated on the actions needed at the inflection points can be beneficial for companies struggling with their R\&D investments. Such work can be potentially implemented on small and medium-sized enterprises (SMEs) in alternative energy who are otherwise aware of the benefits of R\&D but reluctant to practice because they often have to face diseconomies of scale during R\&D activities [94].

This study used the conventional method of identifying curvilinear relationship by including a quadratic term, but some studies have suggested using different conditions for the test of U-shape. For instance, Lind and Mehlum [95] developed on the general framework provided by Sasabuchi [96]. Therefore, it is recommended that future researchers look into all the possibilities of testing a curvilinear relationship. Cautiously chosen construct variables with a well-suited research methodology will certainly increase the accuracy and applicability of the findings, case-by-case.

Though focusing solely on accounting-based measures is effective enough for deriving a workable relationship, it is arguable that integrating market-based measures into the equation could have provided a clearer picture. Therefore, future studies that use marketbased measures or a combination of the two are needed to determine the impact of RDI on $\mathrm{CFP}$ in the alternative energy sector.

Considering that there is no specific theory backing this relationship, the corporate shared value (CSV) theory proposed by Porter and Kramer [97] could provide a meaningful framework. CSV posits that business models integrated with environmental and social issues can result in greater sustainable development. Of ways to create social value, it emphasizes reconceiving products and markets, as well as redefining productivity in the value chain; therefore, it seeks to create a balance between social benefits and economic benefits. A study by Yang and Yan [98] also demonstrated how CSV validates R\&D as a key success factor for heightened innovation and profits in the private sector. Therefore, CSV could be theoretically implemented for testing the R\&D-CFP relationship in the alternative energy industry, but that would require an assessment of the entire circle for shared values, which was out of the scope of this study. However, future researchers may engage in such an assessment.

Funding: This research received no external funding.

Institutional Review Board Statement: Not applicable.

Informed Consent Statement: Not applicable.

Data Availability Statement: The data presented in this study are available as supplementary material.

Acknowledgments: I want to thank Shoeb Ahmed Memon for his guidance and support in shaping this work.

Conflicts of Interest: The authors declare no conflict of interest. 


\section{Appendix A}

Table A1. List of select companies.

\begin{tabular}{cccc}
\hline & Name & Establisher & Country of Origin \\
\hline 1 & Year & USA \\
2 & Ballard Power Systems Inc. & 1979 & Canada \\
3 & Canadian Solar Inc. & 2001 & USA \\
4 & Enphase Energy Inc. & 2006 & U.K. \\
5 & PV Crystalox Solar Plc & 1982 & USA \\
6 & First Solar Inc. & 1999 & USA \\
7 & Gevo Inc. & 2005 & China \\
8 & Ja Solar Holdings Co Ltd. Adr & 2005 & USA \\
9 & Sunpower Corp. & 1985 & China \\
10 & Yingli Green Energy Holding Co Ltd. & 1998 & Denmark \\
11 & Vestas Wind Systems A/S & 1945 & Hong Kong \\
12 & Hanergy Thin Film Power Group Ltd. & 1989 & Taiwan \\
13 & Motech Industries Co Ltd. Gdr & 1981 & USA \\
14 & Cypress Semiconductor Corp & 1982 & China \\
15 & Daqo New Energy Corp Adr & 2007 & South Korea \\
16 & Hanwha Q Cells Co Ltd. Adr & 1999 & USA \\
17 & Ascent Solar Technologies Inc. & 2005 & Germany \\
18 & SMA Solar Technology Ag & 1981 & Canada \\
19 & Westport Fuel Systems Inc. & 1995 & Canada \\
20 & Hydrogenics Corp & 1995 & USA \\
21 & Jinkosolar Holding Co Ltd. Adr. & 1997 & China \\
22 & Tesla Inc. & 2006 & USA \\
23 & Ocean Power Technologies Inc. & 2003 & USA \\
24 & Aerovironment Inc. & 1984 & USA \\
\hline
\end{tabular}

\section{References}

1. Goeschl, T.; Perino, G. On backstops and boomerangs: Environmental R\&D under technological uncertainty. Energy Econ. 2009, 31, 800-809. [CrossRef]

2. Triguero, A.; Moreno-Mondéjar, L.; Davia, M.A. Drivers of different types of eco-innovation in European SMEs. Ecol. Econ. 2013, 92, 25-33. [CrossRef]

3. IEA. World Energy Investment 2017; IEA: Paris, France, 2017.

4. Wüstenhagen, R.; Wolsink, M.; Bürer, M.J. Social acceptance of renewable energy innovation: An introduction to the concept. Energy Policy 2007, 35, 2683-2691. [CrossRef]

5. Kassenga, G. Promotion of renewable energy technologies in Tanzania. Resour. Conserv. Recycl. 1997, 19, 257-263. [CrossRef]

6. Dresselhaus, M.S.; Thomas, I.L. Alternative energy technologies. Nature 2001, 414, 332-337. [CrossRef]

7. Energy Technology Perspectives. Energy Technology Perspectives 2012 Pathways to a Clean Energy System; IEA: Paris, France, 2011.

8. Heidari, N.; Pearce, J.M. A review of greenhouse gas emission liabilities as the value of renewable energy for mitigating lawsuits for climate change related damages. Renew. Sustain. Energy Rev. 2016, 55, 899-908. [CrossRef]

9. Bosetti, V.; Carraro, C.; Duval, R.; Sgobbi, A.; Tavoni, M. The role of R\&D and technology diffusion in climate change mitigation: New perspectives using the witch model. SSRN Electron. J. 2009. [CrossRef]

10. Kesidou, E.; Demirel, P. On the drivers of eco-innovations: Empirical evidence from the UK. Res. Policy 2012, 41, 862-870. [CrossRef]

11. Porter, M.E.; Linde, C. Green and competitive: Ending the stalemate. Harv. Bus. Rev. 1995, 73, $120-134$.

12. King, A.A.; Lenox, M.J. Does it really pay to be green? An empirical study of firm environmental and financial performance: An empirical study of firm environmental and financial performance. J. Ind. Ecol. 2001, 5, 105-116.

13. Pegels, C.; Thirumurthy, M. The impact of technology strategy on firm performance. IEEE Trans. Eng. Manag. 1996, 43, 246-249. [CrossRef]

14. Tsai, T.-H.; Wang, C.-C.; Chiou, J.-R. Can privatization be a catalyst for environmental R\&D and result in a cleaner environment? Resour. Energy Econ. 2016, 43, 1-13. [CrossRef]

15. Dincer, I. Renewable energy and sustainable development: A crucial review. Renew. Sustain. Energy Rev. 2000, 4, 157-175. [CrossRef]

16. Schilling, M.A.; Esmundo, M. Technology S-curves in renewable energy alternatives: Analysis and implications for industry and government. Energy Policy 2009, 37, 1767-1781. [CrossRef] 
17. Jacobsson, S.; Johnson, A. The diffusion of renewable energy technology: An analytical framework and key issues for research. Energy Policy 2000, 28, 625-640. [CrossRef]

18. Jacobsson, S. Transforming the energy sector: The evolution of technological systems in renewable energy technology. Ind. Corp. Chang. 2004, 13, 815-849. [CrossRef]

19. Wen, X.; Guo, Y.; Wei, Y.; Huang, D. How do the stock prices of new energy and fossil fuel companies correlate? Evidence from China. Energy Econ. 2014, 41, 63-75. [CrossRef]

20. Trumpp, C.; Guenther, T.W. Too little or too much? Exploring U-shaped relationships between corporate environmental performance and corporate financial performance. Bus. Strat. Environ. 2017, 26, 49-68. [CrossRef]

21. Pierce, J.R.; Aguinis, H. The too-much-of-a-good-thing effect in management. J. Manag. 2011, 39, 313-338. [CrossRef]

22. Hsieh, P.; Mishra, C.S.; Gobeli, D.H. The return on R\&D versus capital expenditures in pharmaceutical and chemical industries. IEEE Trans. Eng. Manag. 2003, 50, 141-150.

23. Fama, E.F.; French, K.R. The cross-section of expected stock returns. J. Financ. 1992, 47, 427-465. [CrossRef]

24. Vanderpal, G.A. Impact of R\&D expenses and corporate financial performance. J. Account. Financ. 2015, 15, 135-149.

25. Guenther, E.M.; Hoppe, H. Merging Limited Perspectives. J. Ind. Ecol. 2014, 18, 689-707. [CrossRef]

26. Wang, H.; Lu, W.; Ye, M.; Chau, K.; Zhang, X. The curvilinear relationship between corporate social performance and corporate financial performance: Evidence from the international construction industry. J. Clean. Prod. 2016, 137, 1313-1322. [CrossRef]

27. Bobinaite, V. Financial sustainability of wind electricity sectors in the Baltic States. Renew. Sustain. Energy Rev. 2015, 47, 794-815. [CrossRef]

28. Henriques, I.; Sadorsky, P. Oil prices and the stock prices of alternative energy companies. Energy Econ. 2008, 30, 998-1010. [CrossRef]

29. Gupta, K. Do economic and societal factors influence the financial performance of alternative energy firms? Energy Econ. 2017, 65, 172-182. [CrossRef]

30. Yu, F.; Guo, Y.; Le-Nguyen, K.; Barnes, S.J.; Zhang, W. The impact of government subsidies and enterprises' R\&D investment: A panel data study from renewable energy in China. Energy Policy 2016, 89, 106-113. [CrossRef]

31. UNEP. Global Trends in Renewable Energy Investment; Frankfurt School-UNEP Centre/BNEP: Frankfurt am Main, Germany, 2018.

32. Elliott, S.R. Sustainability: An economic perspective. Resour. Conserv. Recycl. 2005, 44, 263-277. [CrossRef]

33. Jaumotte, F.; Pain, N. From Ideas to Development: The Determinants of REDand Patenting (ECO/WKP(2005)44); OECD: Paris, France, 2005.

34. Negro, S.O.; Alkemade, F.; Hekkert, M.P. Why does renewable energy diffuse so slowly? A review of innovation system problems. Renew. Sustain. Energy Rev. 2012, 16, 3836-3846. [CrossRef]

35. Foxon, T.; Gross, R.; Chase, A.; Howes, J.; Arnall, A.; Anderson, D. UK innovation systems for new and renewable energy technologies: Drivers, barriers and systems failures. Energy Policy 2005, 33, 2123-2137. [CrossRef]

36. Buss, D. Examining the ROI of RED; Chief Executive Magazine: Stamford, UK, 2011.

37. Teplykh, G.V. Innovations and productivity: The shift during the 2008 crisis. Ind. Innov. 2018, 25, 53-83. [CrossRef]

38. Arthur, B. Competing technologies: An overview. In Technical Change and Economic Theory; Dosi, G., Ed.; Francis Printer: London, UK, 1988; pp. 590-607.

39. Praetorius, B.; Martiskainen, M.; Sauter, R.; Watson, J. Technological innovation systems for microgeneration in the UK and Germany-A functional analysis. Technol. Anal. Strat. Manag. 2010, 22, 745-764. [CrossRef]

40. Negro, S.O.; Suurs, R.A.; Hekkert, M.P. The bumpy road of biomass gasification in the Netherlands: Explaining the rise and fall of an emerging innovation system. Technol. Forecast. Soc. Chang. 2008, 75, 57-77. [CrossRef]

41. Verbong, G.; Geels, F. The ongoing energy transition: Lessons from a socio-technical, multi-level analysis of the Dutch electricity system (1960-2004). Energy Policy 2007, 35, 1025-1037. [CrossRef]

42. Veugelers, R. Which policy instruments to induce clean innovating? Res. Policy 2012, 41, 1770-1778. [CrossRef]

43. Raven, R.; Verbong, G. Ruling out innovations-Technological regimes, rules and failures: The cases of heat pump power generation and bio-gas production in The Netherlands. Innovation 2004, 6, 178-198. [CrossRef]

44. Bansal, P.; Roth, K. Why companies go greens: A model of ecological responsiveness. Acad. Manag. J. 2000, 43, 717-736.

45. Li, Y. Environmental innovation practices and performance: Moderating effect of resource commitment. J. Clean. Prod. 2014, 66, 450-458. [CrossRef]

46. Rennings, K. Redefining innovation-Eco-innovation research and the contribution from ecological economics. Ecol. Econ. 2000, 32, 319-332. [CrossRef]

47. Wagner, M. On the relationship between environmental management, environmental innovation and patenting: Evidence from German manufacturing firms. Res. Policy 2007, 36, 1587-1602. [CrossRef]

48. Jacobsson, S. The emergence and troubled growth of a 'biopower' innovation system in Sweden. Energy Policy 2008, 36, 1491-1508. [CrossRef]

49. Suurs, R.A.; Hekkert, M.P. Competition between first and second generation technologies: Lessons from the formation of a biofuels innovation system in the Netherlands. Energy 2009, 34, 669-679. [CrossRef]

50. Suurs, R.A.; Hekkert, M.P.; Smits, R.E. Understanding the build-up of a technological innovation system around hydrogen and fuel cell technologies. Int. J. Hydrogen Energy 2009, 34, 9639-9654. [CrossRef]

51. Rivette, K.G.; Kline, D. Discovering new value in Intellectual Property. Harv. Bus. Rev. 2000, 55, 1-14. 
52. Sougiannis, T. The accounting based valuation of corporate R\&D. Account. Rev. 1994, 69, 44-68.

53. Das, A.; Kumar, V.; Kumar, U.; Haldar, R. Impact of R\&D expenditure on financial performance: A study of Canadian IT firms. In Proceedings of the ASAC 2009 Niagara Falls, Ontario, Canada, 6-9 June 2009.

54. Griliches, Z. Issues in assessing the contribution of research and development to productivity growth. Bell J. Econ. 1979, 10, 92. [CrossRef]

55. Pandit, S.; Wasley, C.E.; Zach, T. The effect of research and development (R\&D) inputs and outputs on the relation between the uncertainty of future operating performance and R\&D expenditures. J. Account. Audit. Financ. 2011, 26, 121-144.

56. Dave, P.; Wadhwa, V.; Aggarwal, S.; Seetharaman, A. The impact of research and development on the financial sustainability of information technology (IT) companies listed on the S\&P 500 index. J. Sustain. Dev. 2013, 6, 6. [CrossRef]

57. Ayres, U. Toward a non-linear dynamics of technological progress. J. Econ. Behav. Organ. 1994, 24, 35-69. [CrossRef]

58. Anderson, P.; Tushman, M.L. Technological discontinuities and dominant designs: A cyclical model of technological change. Adm. Sci. Q. 1990, 35, 604-633.

59. Beld, B. The Effects of R\&D Investment on Firm Performance. Master's Thesis, University of Twente, Enschede, The Netherlands, 2014.

60. Orlitzky, M.; Schmidt, F.L.; Rynes, S.L. Corporate Social and Financial Performance: A Meta-Analysis. Organ. Stud. 2003, 24, 403-441. [CrossRef]

61. Van Beurden, P.; Gössling, T. The worth of values-A literature review on the relation between corporate social and financial performance. J. Bus. Ethic. 2008, 82, 407-424. [CrossRef]

62. Lu, W.; Chau, K.; Wang, H.; Pan, W. A decade's debate on the nexus between corporate social and corporate financial performance: A critical review of empirical studies 2002-2011. J. Clean. Prod. 2014, 79, 195-206. [CrossRef]

63. Dixon-Fowler, H.R.; Slater, D.J.; Johnson, J.L.; Ellstrand, A.E.; Romi, A.M. Beyond “Does it pay to be green?" A meta-analysis of moderators of the CEP-CFP relationship. J. Bus. Ethic 2012, 112, 353-366. [CrossRef]

64. Hughes, K. The interpretation and measurement of R\&D intensity-A note. Res. Policy 1988, 17, 301-307. [CrossRef]

65. Cohen, W.M.; Levinthal, D.A. Absorptive vapacity: A new perspective on learning and innovation. Adm. Sci. Q. 1990, 35, 128. [CrossRef]

66. Klapper, L.F.; Love, I. Corporate governance, investor protection, and performance in emerging markets. J. Corp. Financ. 2004, 10, 703-728. [CrossRef]

67. Chen, M.; Cheng, S.; Hwang, Y. An empirical investigation of the relationship between intellectual capital and firms' market value and financial performance. J. Intellect. Cap. 2005, 6, 159-176. [CrossRef]

68. Lin, Y.-F.; Liao, Y.-C.; Chang, K.-C. Firm performance, corporate governance and executive compensation in high-tech businesses. Total. Qual. Manag. Bus. Excel. 2011, 22, 159-172. [CrossRef]

69. Singh, D.A.; Gaur, A.S. Business Group Affiliation, Firm Governance, and Firm Performance: Evidence from China and India. Corp. Gov. Int. Rev. 2009, 17, 411-425. [CrossRef]

70. Heikal, M.; Khaddafi, M.; Ummah, A. Influence analysis of return on assets ( ROA ), return on equity ( ROE ), net profit margin ( NPM ), debt to equity ratio ( DER ), and current ratio ( CR ), Against corporate profit growth in automotive in indonesia stock exchange. Int. J. Acad. Res. Bus. Soc. Sci. 2014, 4, 101-114. [CrossRef]

71. Abiad, A.; Mody, A. Financial reform: What shakes it? what shapes it? Am. Econ. Rev. 2006, 95, 66-88. [CrossRef]

72. Kalemli-Ozcan, S.; Sørensen, B.E.; Yosha, O. Risk sharing and industrial specialization: Regional and international evidence. Am. Econ. Rev. 2003, 93, 903-918. [CrossRef]

73. Kunst, R.M. Econometric Methods for Panel Data; Institute for Advanced Studies: Vienna, Austria, 2016.

74. Lai-xin, L.; Huan-feng, Z. An empirical study on the R\&D inputs performance of high-tech enterprises. J. Cent. South Univ. 2005, 4, 232-236.

75. Chen, Y.-S. The drivers of green brand equity: Green brand image, green satisfaction, and green trust. J. Bus. Ethic. 2009, 93, 307-319. [CrossRef]

76. Porter, M.E.; Van Der Linde, C. Toward a new conception of the environment-competitiveness relationship. J. Econ. Perspect. 1995, 9, 97-118. [CrossRef]

77. Wong, S.K.S. Environmental requirements, knowledge sharing and green innovation: Empirical evidence from the electronics industry in China. Bus. Strat. Environ. 2013, 22, 321-338. [CrossRef]

78. Vachon, S.; Klassen, R.D. Supply chain management and environmental technologies: The role of integration. Int. J. Prod. Res. 2007, 45, 401-423. [CrossRef]

79. Hervani, A.A.; Helms, M.M.; Sarkis, J. Performance measurement for green supply chain management. Benchmark. Int. J. 2005, 12, 330-353. [CrossRef]

80. Agan, Y.; Acar, M.F.; Borodin, A. Drivers of environmental processes and their impact on performance: A study of Turkish SMEs. J. Clean. Prod. 2013, 51, 23-33. [CrossRef]

81. Popp, D. Lessons from patents: Using patents to measure technological change in environmental models. Ecol. Econ. 2005, 54, 209-226. [CrossRef]

82. Merrifield, B. The overriding importance of R\&D as it relates to industrial competitiveness. J. Eng. Technol. Manag. 1989, 6, 71-79.

83. Dowding, K.; Hindmoor, A.; Martin, A. Australian public policy: Attention, content and style. Aust. J. Public Adm. 2013, 72, 82-88. [CrossRef] 
84. Blazejczak, J.; Edler, D. Elements of innovation friendly policy regimes. In Innovation Oriented Environmental Regulation: Theoretical Approaches and Empirical Analysis; Hemmelskamp, J., Rennings, K., Leone, F., Eds.; ZEW Economic Studies: Heidelberg, Germany, 2000; pp. 175-192.

85. Brouillat, E.; Oltra, V. Extended producer responsibility instruments and innovation in eco-design: An exploration through a simulation model. Ecol. Econ. 2012, 83, 236-245. [CrossRef]

86. Dalvi-Esfahani, M.; Ramayah, T.; Rahman, A.A. Moderating role of personal values on managers' intention to adopt Green IS: Examining norm activation theory. Ind. Manag. Data Syst. 2017, 117, 582-604. [CrossRef]

87. Hemingway, C.A.; Maclagan, P.W. Managers' personal values as drivers of corporate social responsibility. J. Bus. Ethic 2004, 50, 33-44. [CrossRef]

88. Song, W.; Yu, H. Green innovation strategy and green innovation: The roles of green creativity and green organizational identity. Corp. Soc. Responsib. Environ. Manag. 2018, 25, 135-150. [CrossRef]

89. Hazarika, N.; Zhang, X. Factors that drive and sustain eco-innovation in the construction industry: The case of Hong Kong. J. Clean. Prod. 2019, 238, 117816. [CrossRef]

90. Li, X. 2012 R\&D intensity and firm performance: Evidence from Chinese manufacturing firms. In Proceedings of the 2012 IEEE ICMIT, Bali, Indonesia, 11-13 June 2012; pp. 45-50.

91. Kitzing, L.; Mitchell, C.; Morthorst, P.E. Renewable energy policies in Europe: Converging or diverging? Energy Policy 2012, 51, 192-201. [CrossRef]

92. Aalbers, R.; Shestalova, V.; Kocsis, V. Innovation policy for directing technical change in the power sector. Energy Policy 2013, 63, 1240-1250. [CrossRef]

93. Bointner, R. Innovation in the energy sector: Lessons learnt from R\&D expenditures and patents in selected IEA countries. Energy Policy 2014, 73, 733-747. [CrossRef]

94. Ortega-Argilés, R.; Voigt, P. Business RED in SMEs; 07/2009; European Commission, Joint Research Centre: Seville, Spain, 2009.

95. Lind, J.T.; Mehlum, H. With or Without U? The Appropriate Test for a U-Shaped Relationship*. Oxf. Bull. Econ. Stat. 2010, 72, 109-118. [CrossRef]

96. Sasabuchi, S. A test of a multivariate normal mean with composite hypotheses determined by linear inequalities. Biometrika 1980, 67, 429-439. [CrossRef]

97. Porter, M.; Kramer, M. Creating shared value. Harv. Bus. Rev. 2011, 89, 62-77.

98. Yang, T.-K.; Yan, M.-R. The Corporate Shared Value for Sustainable Development: An Ecosystem Perspective. Sustainability 2020, 12, 2348. [CrossRef] 